nomy" and Prof. I. I. Rabi "Molecular Beam Radiofrequency Methods for the Study of Excited States of Atoms".

In the evening, Rumford Medals were presented by Dr. Land to Profs. E. Fermi, W. E. Lamb and L. Onsager, who were introduced by Profs. P. Debye, N. F. Ramsey and J. G. Kirkwood, respectively. After the ceremony a reception for the Rumford Medallists was held in the very pleasant rooms of the American Academy of Arts and Sciences. There was also an opportunity of visiting an exhibition of Rumford's seientific works.

On March 28 there was a final symposium on recent developments in nuclear physics. The speakers were Prof. E. Fermi on "Meson Physics", Prof. J. R. Oppenheimer on "Recent Progress in the Understanding of Nuclear Forces", Prof. M. Siegbahn on "Nuclear Spectroscopy" and Prof. V. F. Weisskopf on "Problems of Nuclear Structure". All the symposia were followed by lively discussions, and as there were not more than about a hundred people present the intimate atmosphere contributed very much to the outstanding success of the meetings.

The symposia were organized in a quietly efficient way, and the guests were sincerely grateful for the gracious and generous hospitality accorded to them. Their thanks are due to the officers and staff of the American Academy, in particular to Prof. Harlow Shapley, the chairman of the Rumford Bicentenary Committee, and to Mr. R. W. Burhoe, the executive officer of the Academy.

F. E. SrMon

\section{THE BRITISH DYESTUFFS INDUSTRY}

\footnotetext{
$\mathrm{T}$
}

HE address, "Our Changing Chemical Industries: an Appraisement", which Dr. Herbert Levinstein delivered to the British Association of Chemists on February 27 on the occasion of the award to him of the Hinchley Medal, further expounds a disturbing passage in Sir Henry Tizard's Messel Memorial Lecture last July. Sir Henry Tizard had expressed disquiet at Britain's apparent lack of success in competing in the world's markets for chemicals, and quoted figures to show that our share of world trade in chemicals had gone down steadily from 22 per cent in 1913 to 18 per cent in 1950. Germany had been out of the world's markets twice in this period and her share fell from 37 per cent in 1913 and 36 per cent in 1937 to 11.5 per cent in 1950 . Dr. Levinstein recognized that the chemical industry in Britain is changing in character as, in accordance with the general tendency to expansion across industrial frontiers rather than within them, firms like the Distillers' Co. and the potroleum firms have extended their manufacturing activities far beyond their original field. 'There are now in Britain half a dozen firms, with large capital, making chemicals, whereas formerly there was only one; however, we have not yet begun to reap full advantage of the operations of these big companies.

These changes should substantially strengthen the chemical industry of Britain, diminish dollar imports and help exports ; but nevertheless, Dr. Levinstein urged that there is much to justify Sir Henry Tizard's misgivings. Arguing that in Britain, as in Germany and in Switzerland, the dyestuffs industry is the foundation of organic chemical industry, he suggested that consideration of the beginnings of this industry, the reasons for its leaving its birthplace in Britain, and its growth to really gigantic proportions in Germany would explain much that has disturbed Sir Henry Tizard. Reviewing the beginnings of the industry and its decline in Britain by the 'seventies, Dr. Levinstein said that the absence of a patent law in Germany until 1877 and, until much later, in Switzerland, and of any provision in British patent law for working in Britain, allowed German and Swiss inventors to take out British patents without obligation to manufacture here, while during this period they could infringe British or other patents in their own countries. The weakness of the British patent system was also exploited by the Germans during 1877-1914, after the Imperial patent law of 1877 embodied Caro's definition of a chemical invention, namely, the obtaining of a new and unexpected technical effect.

The imposition in Britain of the same duty on pure alcohol for industrial purposes as on potable spirits also gave a great advantage to the Germans, and this was not modified until nearly thirty years later when the Government wished to make cordite. A further factor was the difficulty in obtaining capital for new and risky developments, a position which persisted until the comparatively recent formation of the Finance Corporation for Industry. Dr. Levinstein dismissed as irrelevant the view that the superior education of the German chemist or the neglect of research by the British manufacturer had played any real part in the transfer of the dyestuffs industry to Germany. It is true, he said, that training in organic chemistry was better in Germany and in Switzerland than in Britain in the early years of the period. The first large and distinguished school of organic chemistry in Britain was under W. H. Perkin, jun., at the Victoria University, Manchester; but there was never any difficulty in obtaining good German, Swiss, or British chemists from abroad. As regards research, Dr. Levinstein claimed that more research was carried out by his firm at Blackley than was justified by the sales, and that, although on a modest scale compared with that of the Germans, far more research was done there than by any other firm in Britain.

Reviewing the achievements in restoring the British industry on the outbreak of war in 1914, and which, in fact, prevented the Germans from using their stocks of dyestuffs for bargaining at the Peace Conference, Dr. Levinstein pointed out that in 1919 imports into Great Britain had fallen to 3,232 tons from 18,900 tons in 1913, and that we were already exporting 5,446 tons. Although the British range of dyes was incomplete and the plants employed were not necessarily the best for peace conditions, the back of the task was broken and a large research organization had been established. Delays in implementing the promise to introduce the Dyestuffs (Import Regulation) Act and other political and economic factors led to the partial dispersal of the research and technical staff; but Dr. Levinstein expressed his concern that a recent book, "Twenty-five Years Ago, the Story of the I.C.I. Merger", issued by Imperial Chemical Industries, Ltd., had not given a fair account of what had been done to re-establish the British dyestuffs industry before that combine was formed. He also contested the claim that the Dyestuffs Act was only intended to protect the home market and not, by securing the home market, to build up exports. The object of the Act was to secure for the home market a wide, substantially complete range of 
dyestuffs; but if exports were neglected, overheads would be extravagantly high. The highest export of British dyestuffs before the Second World War was in 1929, and only in that year and in $1937(5,728$ tons) were the figures for 1919 (5,446 tons) and 1920 $(6,157$ tons) exceeded. In nineteen years under the Dyestuffs Act, nothing was done to increase British exports of dyestuffs.

This, Dr. Levinstein suggested, had some bearing on the figures which caused Sir Henry Tizard concern. Moreover, there had been no further reduction in imports, which averaged 2,325 tons during 1919-26 (including the abnormally high figures for 1920, following the Sankey judgment) and also for 1927-38. The post-war period figures showed improvement. Exports increased to 12,148 tons in 1950 and 12,486 in 1951, and thus do not substantiate the claim that the German firms have recovered their lost ground. On the other hand, imports increased from 786 tons in 1950 to 1,657 tons in 1951, and of these last Dr. Levinstein noted that 676 tons came from Switzerland and 220 tons from the United States, as much being paid to these 'hard currency' countries as we paid to Germany in 1913. Dr. Levinstein also noted that there are now thirty-seven dyestuffs makers in Britain, and he concluded his survey by referring to the potentialities of the small firm and the possibility of formidable competition later from the U.S.S.R. in dyestuffs and in other chemicals.

\section{FOOD PRODUCTS FROM PLANTS}

$\mathrm{T}$

HE Nutrition Panel of the Society of Chemical Industry, at the third of its series of meetings on "Food and the Future", held in the rooms of the Chemical Society, London, W.1, on March 25, discussed the subject of "Newer Sources of Foodstuffs". Two papers were under discussion : one by Dr. A. C. Thaysen, of the Colonial Microbiological Research Institute, Trinidad, on food and fodder yeast, and the other by Mr. N. W. Pirie, of the Rothamsted Experimental Station, on the efficient use of sunlight for food production.

Dr. Thaysen's paper pointed out that the process of making use of waste material as a medium for the growth of yeast is a measure of our shortage of food. The original idea for the use of yeast as a human food was for children in countries experiencing undernutrition where the need for supplementary protein is most acute. The value of yeast lies in its ability to convert about 80 per cent of the inorganic nitrogen supplied into protein. The rate of conversion, compared with more orthodox methods, is enormous : for example, a fully grown bullock, weighing half a ton, produces protein at the rate of $0.9 \mathrm{lb}$. per day half a ton of soya beans at the rate of $82 \mathrm{lb}$. per day; and half a ton of Torulopsis could produce protein at the rate of $5 \mathrm{l}$ tons in $24 \mathrm{hr}$.

Food yeast is at present being produced both in Jamaica and in South Africa. The cost, at 1s. 2d. per lb., corresponds to $0.069 d$. per $1 \mathrm{~b}$. of protein, compared with $0 \cdot 8 d$. per $1 b$. of protein from beef. However, very little yeast is at present consumed by man. In Germany and Finland it is used solely as animal feed, and, if the comparison is then made between yeast and other sources of animal feed, the economic aspect, at the present time, is unfavourable; thus food yeast sells at $£ 130$ per long ton, compared with soya bean meal at $\mathfrak{£ 3 0}$. It is necessary to take into account the presence of an appreciable concentration of vitamins in the yeast. As a supplement to human dietaries, apart from its protein content, yeast would supply much-needed members of the vitamin B-complex and, used in this way, is certainly economical.

In the absence abroad of Dr. 'Thaysen, his paper was introduced by Mr. H. J. Bunker, who emphasized the future possibilities of food yeast, when present economics could be considered irrelevant. He pointed out that dried brewers' yeast sells at $£ 90$ per ton. and when debittered, but not extracted, at $£ 130$.

The value of Torulopsis as a food converter, compared with Saccharomyces, lies in its ability to ferment pentoses as well as hexoses. This is valid only when waste sulphite liquor is used as a medium ; when grown on molasses, both these organisms are equally valuable. Vast quantities of raw material are available: for example, as much as a quarter of a million tons of waste sulphite liquor, which really is a waste material, is available annually in the United States and Canada, as well as hydrolysed wood, banana skins, bracken and peat.

Rhodotorula gracilis could provide a valuable addition to fat resources, as the organism contains 42 per cent fat and 23 per cent protein. Farlier reports of the unpalatability of yeast, when it was said that only about $15 \mathrm{gm}$. per day could be consumed without causing digestive disorders, were probably due to contamination with defrothing agents. Well-prepared yeast is quite palatable.

Mr. Pirie said in his paper that at present we are entirely dependent upon sunlight for our food supplies; but photosynthesis is extremely inefficient. Much of the light is reflected, absorbed by inactive surfaces or by surfaces which are rendered inactive because of unsuitable conditions. The advocates of unicellular photosynthetic organisms, such as Chlorella, dispute that farming is the best way to produce food. Algæ have, however, no greater efficiency in trapping sunlight, but can be more readily made to work at maximum efficiency by provision of optimum temperature, carbon dioxide and nutrients. These conditions would render Chlorella culture as costly as glasshouse cultivation. It was pointed out later in the discussion, however, that efficiencies up to 20 per cent have been achieved by growing Chlorella in the open, as compared with $2-3$ per cent for ordinary crops. In addition, the plasticity of metabolism of the organism permits production of food material of any desired composition : for example, 60 per cent protein : 5 per cent fat or 10 per cent protein : 80 per cent fat.

As tho green plant will be our main source of food for a long time to come, the best use must be made of it. Only a small part of the crop is eaten directly by man ; most is fed to animals or used as a fertilizer, or even wasted. Crops grown primarily as animal food are wasteful, despite the high esteem in which their products are hold, because the overall conversion is usually only 5-10 per cent. Economies in the use of soil can be made both here and by replacing textile fibres by synthetic fibres.

The direct consumption of crops by man is desirable. Plants are, however, relatively poor sources of protein, with the exception of legume seeds and most young leaves. Young, vigorously growing leaves contain up to $30-40$ per cent protein and little fibre; but only a few plant spocies will stand up to continuous cropping of very young leaves. The alternative is to separate the fibre from the proteins, fats and carbohydrates of lower-quality leaves. The 